\title{
Nationalism as Regressive Identitarian Acting Out and Its Destitution Through Democratic Action
}

\author{
Alice Pechriggl* $^{*}$
}

\begin{abstract}
In the following text I would like to juxtapose two types of agency: on the one hand, the acting out of affects of hatred and envy against a projectively imagined other, which is mostly constitutive for nationalism; on the other hand, the deliberative acting on the basis of conflictuality which is constitutive of inclusive democracies, i.e. the ability within a society to resolve conflicts in a civilised way. In doing so, I will draw on the term of acting as enactment or acting out (Agieren), which Sigmund Freud coined for psychoanalysis, but which has since found its way into everyday language.
\end{abstract}

Key words: nationalism, group analysis, multilingualism, monolingualism, identitarin phantasms, psychoanalysis, enactment, political imaginary, theory of action

\footnotetext{
* Institut für Philosophie, Alpen-Adria-Universität Klagenfurt; alice.pechriggl@aau.at
} 
In order to develop the idea of nationalistic acting out as juxtaposed to democratic deliberative action, I will examine the issue in four steps:

1. I will try to make nationalism comprehensible as the acting out of identitarian phantasms marked by the early childhood defence mechanisms of splitting and projection or projective identification. This entails a psychoanalytical perspective on the psychological basis of the ideology of friend vs. foe which is always activated by warmongers and was most fundamentally sanctioned by Nazi lawyers.

2. I will view the phantasmagoria of purity in relation to one's "own" community and the associated phantasm of the purity and unity of language from the perspective of cultural philosophy and philosophy of language.

3. I will try to show that conflictuality is often erased by violent and hateful ways of acting through language: there is hardly a way back into a mode of deliberative action and negotiation so that war and the eradication of the Other are the absolutist horizon of meaning and affect.

4. Finally, I will briefly introduce democratic action as alternating between governing and being governed in the context of conflictuality but also as the differentiation and integration of fragmented parts of the body politics. But if integration is important in itself, it should not be forgotten that at some point it will no longer be possible to negotiate with certain political forces. How can a democracy, how can democrats then act without themselves falling into the trap of the friend-foe rhetoric and into the mode of divisive action?

\section{Nationalism as the Acting Out of Identitarian Phantasms Marked by Splitting and Projection or Projective Identification}

In psychosis, the extreme manifestation of splitting mechanisms, the world splits itself into good and evil, into the phantasm of omnipotence and powerlessness; it is the construction of a world in which the others are perceived as a radical Other or, as Descartes called it, "malin génie", evil genius. Against this evil power phantasised as radical Other, the ego, alternately omnipotent and powerless, has to wage a fight of life and death. Here, trust-in-the-other is negated by permanent and total scenarios of threat, from which the ego can escape only provisionally and only at the price of hallucinatory illusions, religious delusions, pseudo- rationalisations or mystical rituals. The human psyche in general ties to a psychotic core, which does not mean that, in situations of 
heavy threat, all people are immediately befallen by madness. But these structural characteristics of division, rejection, and the related basic assumption of flight-fight (Bion 1961) are found in a weakened form in all people. When they become dominant in a psyche and/or a society they come close to a psychotic acting out. ${ }^{1}$

These modes of perception and related forms of imagining and acting are expressed and sometimes even erupt, particularly in conflictual situations; in situations in which people feel threatened, regardless of whether the threat is real or the result of propaganda. Feelings of powerlessness, which can be accompanied by any kind of threat or dependence, then lead to the reparatory phantasm of omnipotence; more precisely, the psyche tilts back and forth in the course of the split between the phantasms of omnipotence and powerlessness, because it is not able to mediate or integrate these positions. In a kind of escalation of such a heteronomous perception of the world, the phantasms of powerlessness and omnipotence magnify each other. This makes the apparent external determination by the others seem unavoidable and total, if one does not immediately act in terms of the basic assumption of flight-fight, i.e. in a warlike or at least in the friend-foe mode. On the other hand, individual and collective autonomy, i.e. selfdetermination and self-limitation, goes hand in hand with a more realistic assessment of heteronomous conditions and their changeability. What "we", e.g. "we” Austrians, "we” Germans, "we” whites, "we” Europeans, "we” hetero-, homo-, bisexual people assume to be "collective identity" is as much based on illusions as the assumption of an ego that would be the master in one's own house. There is no identity, i.e. self-sameness in the strict sense, neither as pure ego = ego nor as a "we", which would be integer, unbroken and also transparent to oneself. At the same time, the perception of a certain identity of the self is necessary; without this perception people would be at the mercy of the disintegration of thought, that is at the mercy of mental and spiritual confusion. The same applies to politically composed collectives, although their transformability varies greatly, depending on whether we are dealing with a traditional tribal society or with a modern, multicultural city. This is why it cannot be generally claimed that there is no "cultural identity" or that there is just one "cultural identity". The term exists and it refers to something that makes sense in the philosophy of culture and history and which Cultural Studies is concerned with, especially when the question of culturally relevant others arises, or when cultural identity is asserted and claimed by certain groups. It is not enough to logically state that this identity does not exist; it is important to understand the socio-psychological and conceptual modes through which such phantasms are

\footnotetext{
1 For a detailed study of the conceptual differences between acting, acting out and enactment, see Storck 2018; for the difference between acting out and deliberative acting, see Pechriggl 2018.
} 
constituted and how the nationalist ideologues attempt to assert themselves politically; they do so in a hegemonic manner, at the expense of various other groups. To this end, it is necessary to answer the question of how the construction of other people as projective Others in the sense of a radically heteronomous instance has to be situated in the context of the political relationship between autonomy and heteronomy.

So, nationalism is a historical and cultural phenomenon, more precisely it is a phenomenon of modernity that partly goes back to antiquity, insofar as wars between peoples, federations, or empires or communities (poleis) always fall back on central elements of this phenomenon. However, it only began to take on the form that it took in the $19^{\text {th }}$ and $20^{\text {th }}$ centuries with the nation-building processes of, above all, Holland, France, England, etc. and the concept of nation in modern times. With National Socialism, nationalism entered into the phase of its last consequence, that of mass murder and industrial genocide; the wars in former Yugoslavia were a further, albeit differently pronounced form of this exterminatory ethno-nationalism.

The term nation takes different forms, depending on what kind of historical nation we are dealing with (the Paris student community in the Middle Ages also called itself nation); but as a modern political term, it generally refers to a territorial state with a certain form of government and a people that feels attached to this territory and state as home, and that is recognised by this state as citizens or at least as population, according to the regime in place. The Latin word natio confers to this "people" a kind of autochthonystatus with their birth (nacitas; born on this soil), a mythical but nevertheless ethnic characteristic, which makes all newcomers foreigners, and - in the radicalised form of nationalism - enemies to be eradicated. In this nationalist, later explicitly National Socialist ideology of blood and soil, the ius sanguinis increasingly substituted the ius solis so that it was no longer sufficient to have been born on this respective soil of the nation in order to be a citizen. Instead, one had to prove blood ties with already existing citizens.

It is clear that the historical image of "nation" is based on diversity and at the same time on illusionary proclaims of unity in order to subsequently impose it by force. Former U.S. president Obama was right in his speech in South Africa to mark Nelson Mandela's 100th birthday in 2018 when he conjured up an image of France as "la Nation France", a nation that currently seems to be an example of this dialectic of trying to overcome racially or ethnically affected nationalism. The current world champions in football had won with a team made up of more dark-skinned than white-skinned players. Obama commented on this as follows: “...not all of these folks looked like Gauls to me, but they are all French." This clear statement against the ethnic or racial determination of the concept of nation is not only an anti-racist and anti-ethnicist judgement, 
it also refers conceptually to the inevitable migratory foundation of each concrete nation. What is referred to as the migrational background of individual people is at the same time fundamental in and for the history of nations, with the exception of some (linguistic) islands (I am not necessarily thinking of Hungary and its national-fascist tradition...).

As a nationalist construct, the nation is conceived and imagined in the mode of division because from the splitting point of view the contradiction between diversity and unity must be concealed in the name of purity. For this construct, which assumes delusional traits of denial, not only the autochthonous imagination ("born of the earth") but also language is of central importance. What is fundamental for every population, namely this historically proven cultural diversity and the migratory background of most people, is denied. When today a nationalist group in Europe chants "integration is a lie", it does so in exactly this denying way, which is similar to the megalomaniac stylisation of one's own biography that characterises all totalitarian leaders, from Hitler to Stalin to Kim Il Sung. Plato had already referred in the Politeia to the linking of maniac leaders in dictatorial regimes and the maniac dispositions of the ruled people. But the nationalist design of mania was non-existent in Greek antiquity, despite a certain competitive attitude between the Greek poleis and the emphasis on Greek superiority over the Persians after the battle of Salamis, which was fatal for the Persians. But even the most patriotic of all the known Greek tragedies, the Persians of Aeschylus, is full of empathy and compassion for the opponents, whose defeat gave rise to edifying joy in Athenian politics and theatre especially because it had put an end to an all and all destructive campaign against Greece, and in particular Athens.

\section{Language: From Nationalist Monolingualism to Nationalist Speech as an Act of Hate and Destruction of the Other}

Now, a nation state in the weaker, let us say in the common and not in the fanatic sense of the word, sometimes has a single language; sometimes several nations share a language and sometimes - yes, almost always, a nation has several languages, especially when dialects are defined as distinct languages. Austria is an example of a wrested, lost, and oppressed multilingualism, and Israel gave a sad example of this nationalist kind of "monolingualisation" in July of 2018, when the Knesset abolished Arabic as the second official language of the country in order to establish a pure Jewish state in which only Ivrit, Hebrew, is to be spoken. The phantasm of the unity and exclusiveness of the 
national language, the German, the English, the Italian, the Hebrew, or the French language, led to the splitting off of the other languages in these countries. In Austria, the Slavic languages, Hungarian and Italian, but above all Croatian and Slovenian, which theoretically had an official status as national languages since the State Treaty of 1956, fell victim to this separation process.

Monolingualism, that is, the monolingualism of a state that calls itself a nation, is a process of splitting off the other languages and of oppressing those who speak them. I am not speaking here of dialects and so-called local variants as they are tolerated - although not legally anchored - in Austria with the federal principle of the republic (even if people who do not speak Standard German are certainly exposed to a subtle kind of discrimination). Croatian and Slovenian are languages which were spoken by large parts of the population of two federal states - Burgenland and Carinthia, partly also by a third, Styria. These Croatian and Slovenian-speaking parts of the population (in Burgenland many people also spoke Hungarian at the beginning of the 20th century) were considered minorities since the foundation of the 1st Republic of "German Austria", i.e. after the collapse of the empire into various nation states in 1918. During the Nazi regime from 1938 to 1945, they were further repressed, even persecuted and deported, especially the Carinthian Slovenes.

What people who are socialised in the dominant or national language of a country may not notice is the subliminal processes of repression and separation that have been taking place as part of these developments: it is only in the case of conflict that it is often noticed that language barriers are fetishised, just as much as territorial borders in the course of the realisation of the nationalist imaginary. We are dealing here with a very specific way of acting through speaking and, above all, through language suppression, even language prohibition. This way of acting through speaking and through language suppression requires a specific philosophy of language for which both Austin's (Austin 1962) and Butler's (Butler 1997) monolinguistic speech act theories are not sufficient, because their philosophy of language lacks a profound reflexion upon the fundamental relationship between different languages and over all between psyche and body in the act of speaking. This is even more valid for speaking as acting out of affects or passage à l'acte. The embodiment of boundaries, i.e. their physical inscription (relating to the tongue/la langue), is an important element for this. With another language, the motor cortical function changes when speaking and even when dreaming, depending on the language in which one dreams. All questions regarding the transformation of subjects in and through speaking also concern the body, the habitus, hexis in Greek, which Aristotle and, above all, Hegel have understood as a kind of second nature. For people speaking more than one language, monolingualism is a specific kind of forcing the body and the 
psyche by introducing a split, insofar as the censured language lacks in each expression, even during the activity of thinking and dreaming. When censorship is accompanied by terrorist practices like those exercised by the Nazi regime against Slovenes and other 'Slavs', this kind of splitting heavily disturbs the psychic and somatic equilibrium of the people in question, disturbing the process of identification especially in younger people.

The border, both of the ego and of the we-community, the borders of the body and the borders of the territory are all necessary in order to anchor in the people the projective idea of a unity and a selfsameness of the nation imagined as good and pure. The fantasised unity and equality find a kind of hold in these bodily differences and their quasi-religious inflation. This hold is necessary because the interpretation of the unpleasant economic, social, class- and gender-specific differences of power, their blending out and blurring for the establishment of a hallucination of identity and purity of the nation is mere illusion. Like the bodily symptoms and surreal or 'concretistic' body perception in psychotic events, these body differences are supposed to lend reality to the phantasm: the other skin, the other tongue (as language or vernacular), the other reproductive organs or the other shape of the nose seem to have grown (phyein, physis), i.e. naturally grown differently; they can be seen as different by nature and different for ever, because in this phantasmagoria nature itself is seen as an eternal status. As these differences cannot be integrated in the nationalist body politics, they are absolutely and unconditionally to be kept out of the imagined unity and purity, be it at the cost of annihilation.

The nationalist imaginary has always been interwoven with a specific imaginary of the body and of language that borrows from a completely reduced version of biology in order to deny change and in order to fantasise and ideologise the natural growth of the pure nation. If unity is anchored and asserted in one language against other languages, this does not mean that exclusion and demarcation by means of language take place in a more civilised way than if it is anchored in the body, for example against people with a different skin colour or gender. What we are dealing with here are primitive (i.e. early childhood) psychological defence mechanisms that are repeated in the friend-foe pattern and in flight-fight patterns, both at the level of individual psyches and at the level of groups.

Psychoanalytically speaking, the phantasmagoria of purity in relation to one's "own” linguistic community can be described as the fundamental-nationalist language acts (as acting out) in the register of division by means of speech acts. It reduces the enemy in an actualisation of hate affects to features that are split off from one's own community. I call this immediate acting out of friend-foe patterns a mise en acte. At the same time, it is an effective staging (mise en scène), marked by regressive phantasms, reductions, and 
fragments of integrated contexts of meaning and is thus short-circuited with a disintegration, which I call mise en abîme of meaning (Pechriggl 2018). These regressions and disintegrations of meaning go hand in hand with false analogies and the coding of criminal or murderous elements of these acts of speech and thought. (As concerns the language of the Nazis, this was demonstrated, above all, by the linguist Victor Klemperer [Klemperer 1947]). At the same time, it is a language of confusion, of double binds, i.e. of deception through the permanent assertion of the opposite of things that only moments before were still considered as the absolute truth. Such speech act settings are, for example, those in which the branded foreign-speaker or foreign person is described and imagined as excessively dangerous and at the same time (or at the next moment) as incapable of anything; as omnipotent and as busy with the disintegration of a nation imagined to be under constant threat, while always having been presented and portrayed as imbecile and as physically or culturally less advanced. This splitting in the perceiving and imagining of the enemy as imbecile and at the same time as highly dangerous is merely a projective identification, i.e. the projection of one's own omnipotenceimpotence-phantasm onto the supposedly evil Other.

This constantly changing characterisation of the "Other", be it Jew (pretty much everywhere), Slovenian (in Carinthia), homosexual (pretty much everywhere too), Mus$\lim$ (in many traditionally Christian, Hinduist or Buddhist countries), Atheist or Christian (in radicalised Muslim societies), is a typical feature of a divisive perception of the world; it is sometimes attributed to the enemies of the nation, thus characterized as their camouflage or fraudulent nature, but it is another element of the way of thinking in the register of psychic splitting. In order not to let the contradictions become too flagrant, silence is often chosen; this can lead to mutism in the psychopathology of individuals; in Austrian politics, the term "Chancellor of Silence" ("Schweigekanzler") was once chosen for this kind of mutism. But in politics we are never sure if it is more a strategy or an expression of the psychopathology of the politicians. However, in the case of radical nationalism the contact to the hated other is broken off.

\section{Decay of Meaning and Economy of Affect in the Nationalist Imaginary}

The incitement of hatred and hostility against the "other" who is to be eradicated leads to the repeated breakdown of the relationship in which these affect-dispositions originate, if regarded from a developmental perspective on the psyche: Generally speaking, people who act in this way repeatedly suffered from such a break in relationships and 
continuously re-stage such a break ever since their early childhood. Their blatantly displayed tearful disappointment with the state, which has to investigate against nationalists in the case of criminal activities, testifies not only to their infantile psychological constitution, but also to the abrupt change from an omnipotent fantasy of violence to a pathetic attitude of self-victimisation. Chronified and transferred to the outside world, this economy of affect and the associated way of imagining and thinking obstructs the path to dialogue with the other, to negotiation, even to political action in the sense of discussion with the help of empathy and argumentation. For such a debate presupposes conflictuality as the ability to perceive and treat conflicts as negotiable, i.e. to resolve conflicts without falling into a spiral of aggressive fears of - and desires for destruction.

When conflictuality and negotiation are replaced by the eradication of the Other as the absolutist horizon of a nationalist imaginary, the only way out is violence, and not only in language. In this sense, fascism or Nazism is the consistent consequence of nationalist imagining, feeling, thinking and acting. If enough comrades-in-arms imagine and act in this mode, all inhibitions fall, the commandment "Thou shalt not kill" is denied; the murder of the collective "other" declared to be the enemy of the nation is already rationalised by the language described above, i.e. ideologically legitimised as self-defence. If in the nationalist imaginary war and the eradication of the other, who threatens the hallucinated identity and purity of the nation, become - as mentioned the absolutist horizon of meaning and affect, then this also relates to an unconsciously hoped - for repair of the broken ego of those people who want to assert such a nation with rhetorical force and, in last consequence, with armed violence. It is not dialogue, empathy, and solidarity in dealing with shared suffering, as they are usual in times of 'civilised' coexistence of different people, that are on the agenda, but the warlike establishment of absolute borders between the nationalistically constituted "we" and the "other" who threatens this "we" as an enemy. Whoever tries to cross this border, which is both imaginary but also often physically erected, is destroyed, first in the imagination and linguistically, then physically by internment and annihilation or execution.

We are currently witnessing a massive increase in such a rhetoric of annihilation and concentration against refugees and migrants, not only in Europe, but also in the USA, which should alarm us, and which should be countered if we do not want to enter into another phase of barbarism. 


\section{Conflictuality and Radical Democratic Action}

This deadly, primitive-psychic acting out in the sense of the friend-foe logic can be countered by means of a radical-democratic acting as alternating governing and being governed in terms of conflictuality. This kind of action must not be seen as the other side of the coin of acting out in the name of division, but as a more deliberative action that tries to become aware of these elements of acting out on the part of both the individual members of a collective and the collective as a whole by taking them into account when the respective group finds itself in a conflict.

On the one hand, this democratic acting in situations of conflictuality involves the differentiation between - and integration of split elements. On the other hand, it involves the analysis of the conflict as one to be negotiated and not as one to be acted out in a warlike manner. It is a different kind of political economy of affect, which enables not only democratically pluralistic-minded people, but also war-minded people to find their way back into a language, a way of thinking and feeling, through which the other, every other person, is not a priori seen and treated as an enemy, but always already as an alter ego, i.e. as another, whose perspective is just as constitutive for the self as the affective, social, and above all legal-political recognition by others. A nation that wants to be democratically governed (or to put it in radical democratic terms: "that wants to govern itself democratically") must practise these manners: in parenting, education, and above all in the civic and political handling of differences, conflicts of interest, and affects, however challenging they may be.

But what if, in a democracy, groups grow stronger that want to remain in the mode of division, that construct others as enemies in order to fight, expel, or destroy them, and that find more and more followers, even dictating their rhetoric to those in power, as is more and more the case in Hungary, Poland, Austria, Italy, etc.? These nationalist tendencies, which manifest themselves through a fascist-violent behaviour, can only be overcome by a decided demarcation, by way of showing them their place, without succumbing to the friend-foe ideology and the actions associated with it. Critical and analytical opposition to nationalism has always been a first step in the fight against fascism. Above all, however, importance must be given to the critique of representation. While the regime of representation places individuals under the principle of long-term representativeness and substitutability, the critique of it does justice to everyone (in the sense of 'one person, one vote', germ. Stimme, which also means 'voice'). The critique of representation is concerned with not inflating differences into stereotypes and with understanding the people as multitudes constituted by irreducibly different individuals and not as an amorphous mass, or even as a mob. On the political-procedural level, this has serious consequences: it requires an effective voice for each citizen and the ability to 
exercise power for all of them, of course in the sense of the Aristotelian principle of alternating governing and being governed. Thus, while democracy gives everyone a voice, fascism and totalitarian regimes, but also authoritarian parties, see individuals as interchangeable and treat them as movements dominated by authoritarianism under the will and imagination of the leader, according to the motto 'One for all, all for one'. If the realisation of the fantasy of national-political purity and delusion fails, as was fortunately the case at the end of the Third Reich, the masses so delusionally represented must also fall. We know that Hitler found it only right and proper to flood the people of Berlin, who had found refuge in the underground shafts, towards the end of the war and thus to surrender them to certain death: because a people who do not win this war for their leader is - according to the 'leader' himself - not worth to continue living. This makes it easy for us to see how the hatred of others, which I mentioned at the beginning, is inextricably linked with the hatred of the self: Hitler, and many others in power, also took their own lives shortly afterwards.

So, let us beware of the prophets who have so often been hallucinating about national unity and purity. These topoi are always acted out in the register of the urge for death, and if they are not stopped, they inevitably bring death, and they do so on a massive scale. Even if they do this in Europe at present mainly only rhetorically, both rhetoric and deeds are already murderous in the Mediterranean, when it comes to boat refugees. The obstruction of the rescue of people in distress at sea, as attempted by a group of the Austrian and German Identitarian Movement in 2017 by means of a ship specifically hired to that purpose, not only violates international maritime law, but is an anticipated murder. As fate would have it, these people found themselves in distress at sea with their hired ship. The fact that they did not accept the help offered to them by those whom they had wanted to obstruct, i.e. the NGO ships rescuing boatpeople in the Mediterranean Sea, is only one sign for their divided souls.

There has been long enough time to be vigilant, now vigilance alone is no longer enough, it is time to start acting, especially by the so-called media, which already give more and more space to the nationalist rhetoric and thus contribute to its propagation, that is also to say to making national fascism capable of winning a majority, overlooking the fact that fascism would then obviously abolish them as free media or bring them into line, as in Hungary, Russia, Turkey, etc. What exactly can be done cannot be answered in principle. In crisis situations nobody is immune from creating divisions or from falling into the projective logic of friend vs. foe. As long as people are episodically or in their private fantasies caught up in this logic of affect and action, one can try to enter into an exchange, a conversation with them. If, however, an extreme right-wing po- 
litical movement forms on the fringes of unconstitutionality, we should consider other political strategies.

It is certainly good to rely on the institutions established to protect the democratic constitution (even if it upholds only a representational democracy), such as the Constitutional Service in Austria. But if, as is currently the case in Austria, a Minister of the Interior, shortly after his "democratic" seizure of power, allows the Constitutional Service to be attacked, then it should be clear to everyone that this trust could be fatal for the democratic regime; and it should be clear that civil society must act politically in order to push back this kind of nationalist-authoritarian rule, and to do so with all available democratic, rhetorical, and political means. Not only singers, artists, and scientists, but the entire population is called upon to get involved or to finally start thinking. Together, the multitude has the power to re-civilise public discourse and thus also politics: because, ultimately, the power is - as Arendt stated and as French people have been showing since the winter of 2018 - on the streets; it is not only in party or police headquarters.

\section{References}

Austin, John. 1962. How to Do Things with Words. Oxford: Clarendon Press.

Bion, Wilfred Ruprecht. 1961. Experiences in Groups. London: Tavistock.

Butler, Judith. 1997. Excitable Speech. New York: Routledge.

Klemperer, Victor. 1947. LTI. Notizbuch eines Pbilologen. Berlin: Aufbau Verlag.

Loraux, Nicole. 1997. La cite divisée. Paris: Payot. (engl. transl. The divided city, New York 2002, Zone Books).

"Obama says we're in 'strange and uncertain times' in Mandela lecture" CBS News. July 17, 2018. https:// cbsn.ws/2JvbZjQ

Pechriggl, Alice. 2018. Agieren und Handeln. Bielefeld: Transcript.

Storck, Timo. 2018, “Worum handelt ES sich beim Agieren?” In Enigma Agency, edited by Hans-Herbet Kögler, Alice Pechriggl, Rainer Winter, 115-136. Bielefeld: Transcript. 